\section{The Impact of Digital Technology to Change People's Behavior in Using the Media}

\author{
Dendy Suseno Adhiarso*, Prahastiwi Utari, Sri Hastjarjo \\ Master of Communication, Faculty of Social and Political Sciences, Universitas Sebelas \\ Maret, Indonesia \\ *e-mail: dendysuseno@gmail.com
}

\begin{abstract}
The development of digital technology very rapidly at this time has made all kinds of media fused into the entire life of the community. So that makes humans becoming addicted always to utilize the technological sophistication. Not only in the context of technological progress physically but the impact of technical complexity that has affected the community, either way, we communicate, interact, transact and how society. This study aims to determine how the effect of technological sophistication to change people's behavior in using the media. The theory used in this study is a digital theory, behavior change theory, media theory and the theory of convergence. This research is a qualitative descriptive study that seeks to explain and describe the real situation in society at this time by combining secondary data types. Data were analyzed to formulate a prediction for the future based on data from prior periods to obtain a picture of reality past, present, and future on the changes that occur. The results showed that the new media has an impact on the behavioral change in the use of media that has implications for social change, culture, economy, and politics.
\end{abstract}

\section{Keywords}

Digital technology, new media, change behavior

\section{Introduction}

The era of globalization has a powerful influence on all dimensions of public life. It leads to social changes, both positively and negatively. Technological developments make society must accept the presence of the problems that are structural which then penetrated all aspects of life. Associated with technological developments that have an impact on modernization, information technology is the fastest growing and direct influence on the level of civilization. If globalization is defined as the development of human culture, the globalization of information and communication is the real impact on the development of communication technology (Xiang et al., 2015). Information in any form can be distributed quickly and quickly so influence the worldview, lifestyle, behavior, and culture of a nation. The flow of data very quickly leads to a lot of people who are not able to filter the messages you receive, so unconsciously that information has gradually 
affect patterns of behavior and culture in the community. The perception that has long existed and becomes a benchmark

public's attention. As a result, the longer the social changes in the community began to rise to the surface. Currently almost lost and separated from the public's attention. As a result, the longer the social changes in the community began to rise to the surface (Dovidio et al., 2009).

The most different impact is felt among the public is that changes in lifestyle and behavior patterns that require people to be almost instantaneous, thus causing a shift in cultural values in public life. Digital technology has made all kinds of media fused into the entire life of humans. The unification of various press is known as media convergence (Herkman, 2012). Convergence is not just happening in technology, but also occurs in the culture of the community. Mode reading, listening, watching the media is no longer with the separate but technically it all together and the more freely (technology savvy) in the grip of a man who always moving (mobile) (Meikle \& Young, 2011). Furthermore, the convergence of media technology in the context of social significance. Communities are moving toward a unification of digital culture that makes the world's population are in a global village (global village). No more traditional barriers that separate people, all of which interact cross-culturally (Creeber \& Martin,2008). But behind the rapid development of information technology, the change has the effect of outstanding against the habits of today's society. The fact can be seen from the way today's society to communicate or interact. In today's world, people are more likely to communicate through electronic media and internet media.

In contrast with the past, that tends to communicate with the media face to face. The use of new media today is dominated by teenagers. Facebook, Twitter, Instagram, media skype is the most popular social networks today. Through their social networks to exchange information to meet its needs. By using social networking can also shorten the time and be more efficient in interacting. But besides that, using social networks also have a negative impact, one of the adverse effects is growing laziness of a person to meet people directly when interacting because too comfortable using social networking. It makes people more anti-social.

The purpose of this study was to describe the changes that occur in society as the user audience of media, both traditional media and new media such as online media.

\section{Theoretical Framework}

\subsection{Digital Theory}

Digital theory is a concept of the understanding of the times on Science and Technology, of all that is manual to automatic and all that is complicated becomes rapid. Digital is a sophisticated and flexible method which makes it something essential in human life. Digital theory is always associated with the media because media is something that is continually evolving. Many people are still not familiar with New Media is a media formed from human interaction with information and communication technology (Morris \& Higgins, 2010). Examples of new media including the internet, mobile phone, social networks, web, etc. While the old media is the foremost pioneers that can connect people and information. Examples of old media include newspapers, radio, and TV.

\subsection{Behavior Change Theory}

The behavior is the result of the relationship between stimulus and response. Such behavior is divided into three domains, namely cognitive, affective and psychomotor. Cognitive measured based on knowledge, effective measured by attitude, during psychomotor of action. The formation of behavior can occur because of the process of maturity and the result of the process of interaction with the environment. Change can happen at any time and is a dynamic process and cannot be avoided (Ryan, et al., 2011). In the process of formation or change behavior is influenced by several factors that come from within ourselves. These factors include the central nervous system, perception, motivation, emotion, and learning. Behaviors that applies to an individual or organism does not happen automatically. But as a result of the stimulus received by the body in question. Both the external and internal stimuli stimulus Behavior can be observed, either directly, such as laughing, drinking and so forth or indirectly such as thoughts and feelings. The behavior of society is formed from the environment in which it lives. This behavior lasted quite a long time and even continues to this day. Also could have the same action from 
generation to generation in the community. This could be a new culture for the individual and society in the region (Cowan et al., 2013).

\subsection{Media Theory}

Study of new media emerged as one of the branches of communication theory as the claim that the traditional media environment is facing the challenges of technological innovation (Potter, 2011). One of the substantial changes to media made Marshall McLuhan, the inventor of the term media in the Electronic Revolution: Electronic Effects of New Media. McLuhan argued that the influence of the electronic revolution in the 1950s in the United States that makes the educators one puts people's lives in a world little is done to another in which they grow. For McLuhan, this revolution produces a classroom without walls as telecommunications and television bring a sustainable information structure for society. Besides McLuhan suggests that the effects of the new technologies of communication occurred not only at the level of knowledge and opinions consciously. Technology can also affect people on a subconscious level (subliminal) of the ratio of sense and perception patterns so that McLuhan said that "the medium is the message." For McLuhan technological developments from the perspective of a contemporary look at the language itself already serves as a tool, the message is there in the media and vice versa (McLuhan \& Zingrone, 1997).

\subsection{Convergence Theory}

This theory states that the formation or development of one's personality is determined by innate factors and also factors in the surrounding environment. While the definition of media convergence is not only a shift in technology or process technology but also including a change in the paradigm of industrial, cultural, social and encourages consumers to seek new information (Jensen, 2010). Media convergence occurs by looking at how people interact with others on a social level and use a variety of media platforms to create new experiences, new forms of media and content that connect each person socially, and not only to other consumers but for producers of companies' media. Movement of growing media convergence in particular from the rise Internet and digitization of information, This media convergence that unites computing 3C (enter data via computer), communication (communication), and content (material content/content) (Quandt \& Singer, 2009). So, the theory of media convergence is a process that occurs following the development culture community.

\section{Method}

This research is a qualitative descriptive study that seeks to explain and describe the real conditions in society today, especially those who use communication devices and telecommunication in the form of proportion, characteristics, and so on. Furthermore, the research approach used is qualitative research that combines secondary data types. Data were analyzed to formulate a prediction for the future based on data from prior periods to obtain a picture of reality past, present, and future on the changes that occur.

\section{Results and Discussion}

The new medium is a medium that offers digitization, Convergence, interactive, and the development of associated network message creation and delivery of the message. The ability to provide this interactivity gives users of new media have the option of what information is consumed, as well as controlling the output of data generated and perform the desired options. New media or social media does have the ability to cover a broader range of interactive and interacting with others. Currently, social media has become a medium of communication that is widely used in social processes (Hennig-Thurau et al., 2010). The general form of social process social interactions can also be called a social process. Social interaction is a crucial condition for the occurrence of social activities. Social interaction is social relations dynamic concerning the relationship between individuals, between groups with the group, as well as between individuals and groups. Human communication begins with face to face then the longer emerging media to communicate 
so that the media is more complicated. Social interaction can occur in various ways, such as to admonish one another, shaking hands, to talk, to fight, and it all can be said of social interaction.

Social interaction is essential in human life. One example of socializing and communicating with both the individual and the group. While the terms necessary for social interaction are: The existence of social contacts and Communication. In the social interaction is an interaction must not touch or deal with the speaker, this time with the development of technology people can relate to other people via telephone, radio, television, and the discussion today is the internet. In social contact, interaction with the media is included touches are secondary, but people will often not implement the connection that is of primary human contact that occurs when coming into contact directly meet or face to face.

The development of increasingly sophisticated technology is the reason human society becomes individualistic; it is evident that the emergence of the Internet as a bridge to connect the new media such as social media and so capable of being a substitute for interacting media to other individuals. Nowadays it can be said the community has been hypnotized by the presence of new media that provides all the ease in interacting bridged by a press. The new press includes all known societies mainstream media such as radio, television, and so on. With a population of Indonesia now reaches 262 million people. More than 50 percent or about 143 million people have been connected to the Internet network throughout 2017. The majority of internet users still as much as 72.41 percent of the urban community. Utilization has been further, not only to communicate but also to buy things, book transportation, to do business and create. Based on the geographic region, most of the Java community as the 57.70 percent of Internet users. Furthermore, 19.09 percent of Sumatra, Kalimantan, 7.97 percent, 6.73 percent Sulawesi, Bali- Nusa 5.63 percent and 2.49 percent Maluku-Papua. While according to age range, as much as 49.52 percent of Internet users in the country are those aged 19 to 34 years.

These groups endorse new professions in the realm of cyberspace, such as Telegram (celebrities Instagram) and YouTubers (YouTube creators). The proliferation of digital startups or startup was moved by this age group, whether they be the founder or consumers. In the second position, as many as 29 , Indonesia 55 percent of Internet users aged 35 to 54 years. This group is in the productive age and adaptable to change. Adolescents aged 13 to 18 years in third place with a share of 16.68 percent. Lastly, the elderly over 54 years, only 4.24 percent of that use the Internet. The level of education and economic level addition to age, educational factors affecting Internet penetration in Indonesia. A total of 88.24 of them were educated master and doctoral connected to the Internet. The majority of graduates and diploma also have used the Internet, which is as much as 79.23 percent. Of the 143 million people of Indonesia are already connected to the Internet, there are approximately 62.5 million lower-middle-class people who use the internet. While the upscale community of 2.8 million people ("Berapa Jumlah Pengguna Internet Indonesia?" n. d.).

Based on the data above, the advent of new media slowly weakens the values and norms in society, such as today's youth who spend more time with gadgets and interact in a virtual world. It stands to reason that the teenager is hard to socialize in the community because the actual interaction processes or associative processes are carried out is lacking. With such a phenomenon that the values and norms of a society increasingly lost and associative processes in an organization will also be lost so that it appears people are individualists. Some of today's society it is difficult to interact with others, but they can communicate in a virtual world, even some people have to have a community therein. The new media is indeed causing associative process carried out in society to be weak, but the new media facilitates individuals and groups in the process of interaction in the virtual world, so it appears they called the cyber organization.

Currently, Indonesia is considered the Asian giant digital technologies that are asleep. Indonesia with its population of 250 million people is a huge market. Indonesian smartphone users are also overgrowing. Digital marketing research agency eMarketer estimates that by 2018 the number of active users of smartphones in Indonesia for more than 100 million people (KOMINFO, n.d.). With that amount, Indonesia will become the country with the fourth largest smartphone active users in the world after China, India, and America. Information technology is growing in Indonesia has created a new culture in the public sphere, of course, for today's sophisticated technology has brought changes in mass scale, changing the shape of the local world community into a global world community.

Advances in technology today are increasingly global society herded towards a social end. This process as a result of modernization that has reached an extreme point, which is referred to as contemporary hypermodernists. The stark reality is now making its users competing to use social media. The social end also marked by social transparency is a condition disappearance of social conditions. New media to develop the space for a new life for the people so that without realizing it, the human community has been living in the two entities, the presence of a real neighborhood and virtual community life 
(cybercommunity). Real community is a community life that the senses can be perceived as real life, where social relations among members of the city built through sensing. While the virtual community is a community life that cannot be seen directly through human senses but can be felt and seen as a reality.

Currently, people are in two lives, consciously and their real lives in the real world that demands to interact directly with other individuals, but they also play an active role in the virtual world as media convergence someone in the real world or interact chat, send messages, upload photos, and so on. Cyber virtual community or society to establish itself with relying solely on social interaction and social processes in the life of a group (network)- and fellow members of the virtual community. Social processes and social interaction in virtual communities, there are temporary, and some are to be settled in a relatively long time. While social interaction occurs as the user only play in the virtual world through browsing, chat and then leave. While the social interaction that settled like social interaction and group life that lasts long enough among members of other virtual communities. Internet users as this are referred to as a cyber community because whatever he does in the virtual world like hanging out, say hello, make love, do business, learn and even steal, and so on.

Social media is now a place to perform any activity for the community; the community creates interactions in the virtual world has surpassed the world hyperreality. So today's society tends to be classified as a cyber community because in everyday life can never be separated with information technology. Therefore, today's society is relative can be said only become part of the cyber community, because they have two worlds, the real world where they indulge in a practical and virtual world, they also indulge artificially

Media today has shaped a mindset, attitude, and action or behavior for every individual who will bring people into the lifestyle of almost instantaneous but more effective. The development of new media also has a positive impact on improving the quality of life, where the new press as an asset concerning information and communication technology revolution, which affects, among others: Advances in information processing power can expand the talent and abilities. The new systems will ensure greater personal comfort in each. Individuals will enjoy not only higher efficiency in performing daily tasks, but more significant interaction with people and other interests, so it stimulates creativity and personal participation. The development of new media is not only a positive impact but also has negative consequences on users who do not use and do not use new media with standard capacity. Excessive use will cause collisions with real life and the clash of cultures. The negative impact arising from the emergence of new media are: the pollution of the many emerging information with false news or a hoax, a sense of social and solidarity are getting lower, the advent of instant culture, the spread of technology crimes such as copyright infringement or piracy (cybercrime) and growth of hedonism and consumer attitudes.

\section{Conclusions}

Highly developed information technology today has created a new culture in the public sphere, of course, with today's advanced technology has brought changes in mass scale, changing the shape of the local people of the world into a global world society without time and space limitation. With the advent of new media that offers digitization, and interactive Convergence offers users to choose what information you want to eat. Meanwhile, the social media is one of the new media that bring significant impact to the society, which is changing the world to be very transparent to the development of information, transportation, and technology is so fast and so big influence world community. The development of online media access in Indonesia has been growing new habits and culture of media for individuals and society that has implications for social change, culture, economy, and politics. Therefore attack new media cannot be prevented, but new media is not entirely a negative impact on society, because the new media also has many positive effects, so it can be used to support the improvement of people's lives to be more advanced and modern but still hold firm culture Indonesia. This research is still straightforward so that the expectations of the researchers is their advanced study deeper and broader, to provide an overview and a positive impact on improving people's lives Indonesia in the use of media. 


\section{References}

1. Bohang, F.K. (2018) Berapa Jumlah Pengguna Internet Indonesia? - Kompas.com. (n.d.). Retrieved September 30, 2018, from https://tekno.kompas.com/read/2018/02/22/16453177/berapa-jumlah-pengguna-internetIndonesia

2. Cowan, L. T., Van Wagenen, S. A., Brown, B. A., Hedin, R. J., Seino-Stephan, Y., Hall, P. C., \& West, J. H. (2013). Apps of Steel: Are Exercise Apps Providing Consumers with Realistic Expectations? A Content Analysis of Exercise Apps for Presence of Behavior Change Theory. Health Education \& Behavior, 40(2), pp. 133-139.

3. Creeber, G., \& Martin, R. (2008). Digital Culture: Understanding New Media: Understanding New Media. McGraw-Hill Education (UK).

4. Dovidio, J. F., Gaertner, S. L., \& Saguy, T. (2009). Commonality and the complexity of "we": Social attitudes and social change. Personality and Social Psychology Review, 13(1), pp. 3-20.

5. Hennig-Thurau, T., Malthouse, E. C., Friege, C., Gensler, S., Lobschat, L., Rangaswamy, A., \& Skiera, B. (2010). The impact of new media on customer relationships. Journal of Service Research, 13(3), pp. 311-330.

6. Herkman, J. (2012). Convergence or intermediality? Finnish political communication in the New Media Age. Convergence, 18(4), pp. 369-384

7. Jensen, K. B. (2010). Media convergence: The three degrees of network, mass and interpersonal communication. Routledge.j

8. KOMINFO, P. (n.d.). Kementerian Komunikasi dan Informatika. Retrieved September 24, 2018, from https://kominfo.go.id/

9. McLuhan, E., \& Zingrone, F. (1997). Essential McLuhan. Routledge.

10. Meikle, G., \& Young, S. (2011). Media convergence: Networked digital media in everyday life. Macmillan International Higher Education.

11. Morris, R. G., \& Higgins, G. E. (2010). Criminological theory in the digital age: The case of social learning theory and digital piracy. Journal of Criminal Justice, 38(4), pp. 470-480.

12. Potter, W. J. (2011). Conceptualizing mass media effect. Journal of Communication, 61(5), pp. 896-915.

13. Quandt, T., \& Singer, J. B. (2009). Convergence and cross-platform content production. The Handbook of Journalism Studies. Ed. Karin Wahl-Jorgenson \& Thomas Hanitzsch. New York: Routledge pp. 130-144.

14. Ryan, R. M., Lynch, M. F., Vansteenkiste, M., \& Deci, E. L. (2011). Motivation and Autonomy in Counseling, Psychotherapy, and Behavior Change: A Look at Theory and Practice 1 47 . The Counseling Psychologist, 39(2), pp. 193-260.

15. Xiang, Z., Magnini, V. P., \& Fesenmaier, D. R. (2015). Information Technology and Consumer Behavior in Travel and Tourism: Insights from Travel Planning Using the Internet. Journal of Retailing and Consumer Services, 22, pp. 244-249. 